\title{
Serine Protease Inhibition Reduces Post-Ischemic Granulocyte Recruitment in Mouse Intestine
}

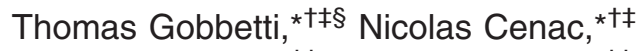 \\ Jean-Paul Motta, ${ }^{\star \dagger \ddagger}$ Corinne Rolland, ${ }^{* \dagger \ddagger}$ \\ Laurence Martin, ${ }^{* \dagger \ddagger}$ Patricia Andrade-Gordon," \\ Martin Steinhoff, " Elisabetta Barocelli, ${ }^{\S}$ and

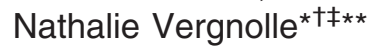 \\ From INSERM,* U1043, CNRS, ${ }^{\dagger}$ U5282, and the Universite de \\ Toulouse, ${ }^{\ddagger}$ UPS, Centre de Physiopathologie de Toulouse Purpan \\ (CPTP), Toulouse, France; the Department of Pharmacological, \\ Biological and Applied Chemical Sciences, ${ }^{\S}$ University of Parma, \\ Parma, Italy; $R W$ Johnson E Johnson, "I Spring House, \\ Pennsylvania; the Departments of Dermatology and Surgery," \\ University of California San Francisco, San Francisco, \\ California; and the Department of Physiology and \\ Pharmacology,** University of Calgary, Calgary, Alberta, Canada
}

Proteases and proteinase-activated receptor (PAR) activation are involved in several intestinal inflammatory conditions. We hypothesized that serine proteases and PAR activation could also modulate the intestinal injury induced by ischemia-reperfusion (I-R). C57B1/6 mice were subjected to 90 minutes of intestinal ischemia followed or not by reperfusion. Sham-operated animals served as controls. After ischemia, plasma and tissue serine protease activity levels were increased compared to the activity measured in plasma and tissues from sham-operated mice. This increase was maintained or further enhanced after 2 and 5 hours of reperfusion, respectively. Trypsin (25 kDa) was detected in tissues both after ischemia and 2 hours of reperfusion. Treatment with FUT-175 (10 $\mathrm{mg} / \mathrm{kg}$ ), a potent serine protease inhibitor, increased survival after I-R, inhibited tissue protease activity, and significantly decreased intestinal myeloperoxidase (MPO) activity and chemokine and adhesion molecule expression. We investigated whether serine proteases modulate granulocyte recruitment by a PAR-dependent mechanism. MPO levels and adhesion molecule expression were significantly reduced in I-R groups pre-treated with the $\mathbf{P A R}_{1}$ antagonist SCH$79797\left(5 \mathrm{mg} / \mathrm{kg}\right.$ ) and in $\mathrm{Par}_{2}{ }^{-/-}$mice, compared, respectively, to vehicle-treated group and wild-type littermates. Thus, increased proteolytic activity and PAR activation play a pathogenic role in intestinal I-R in- jury. Inhibition of PAR-activating serine proteases could be beneficial to reduce post-ischemic intestinal inflammation. (Am J Patbol 2012, 180:141-152; DOI: 10.1016/j.ajpath.2011.09.031)

Acute mesenteric ischemia is a potentially fatal abdominal emergency implicated in a large array of pathological conditions that involve a critical reduction of blood flow to the gut as consequence of surgical states (abdominal aortic aneurism surgery, cardiopulmonary bypass), vessel occlusions (embolism or thrombosis), septic or hemodynamic shock, intestinal hernias, and also transplants of the small intestine. ${ }^{1-3}$ Although acute mesenteric ischemia accounts for only $1 \%$ to $2 \%$ of gastrointestinal illnesses, it still causes a high in-hospital mortality rate $(60 \% \text { to } 80 \%)^{3}$

The pathogenesis of ischemic injury is related to the interruption of blood supply to the gut, which results in rapid metabolic damage to active tissues, particularly to the labile cells of mucosa. Paradoxically, reoxygenation, depending on the time and intensity of the ischemia, further increases the damage, causing an additional cell injury known as reperfusion injury. This acute inflammatory response causes a rapid deterioration of the intestinal barrier, leading to intestinal bacterial translocation through the epithelial mucosa to extra-intestinal sites (mesenteric lymph nodes, liver, and spleen)., 3 The subsequent sepsis and production of proinflammatory molecules leads to the development of a systemic inflammatory response syndrome, which can progress to multiple organ failure involving organs such as liver, heart, kidneys, and lungs. ${ }^{2,5,6}$

Proteases, particularly serine proteases, act as signaling molecules that are able to send specific signals to cells involved in intestinal inflammatory responses through the activation of a subclass of four G protein-

Supported by INSERM-Avenir program, Agence Nationale de la Recherche, Fondation Bettencourt-Schueller, and Fondation Schlumberger (N.V.).

Accepted for publication September 20, 2011.

Address reprint requests to Nathalie Vergnolle, Ph.D., INSERM U1043, CHU Purpan, BP3028, 31024 Toulouse-Cedex, France, Tel: (+33) 562744500. E-mail: nathalie.vergnolle@inserm.fr. 
coupled proteinase-activated receptors $\left(\mathrm{PAR}_{1}, \mathrm{PAR}_{2}\right.$, $\mathrm{PAR}_{3}$, and $\left.\mathrm{PAR}_{4}\right)^{7-12}$ To activate those receptors, which are largely expressed in the gut, proteases cleave at specific sites within the extracellular $\mathrm{N}$-terminus domain of PARs. This cleavage unmasks a new N-terminal sequence that acts as a tethered ligand, which binds to the receptor to initiate multiple signaling cascades. ${ }^{8}$ Several findings report that direct injection of proteases such as thrombin, trypsin, tryptase, or selective agonist for $\mathrm{PAR}_{1}$ and $\mathrm{PAR}_{2}$ into the paw of rodents produces inflammation. ${ }^{13-15}$ In addition, we have demonstrated that luminal administration of selective peptides, agonists for $\mathrm{PAR}_{1}$, $\mathrm{PAR}_{2}$, and $\mathrm{PAR}_{4}$ provoked a colonic inflammatory response. ${ }^{16-21}$

All these observations provide the background for the hypothesis that proteases and PARs could play a major role in the pathogenesis of intestinal inflammation associated with ischemia-reperfusion (I-R) injury. Although a role for proteases in ischemic tissues has been suggested in kidney, ${ }^{22}$ liver, ${ }^{23,24}$ heart, ${ }^{25,26}$ and digestive tract, ${ }^{27,28}$ it is not clear what role proteases may play in ischemic disorders of the intestine, which is, above all, the organ the most exposed to a variety of proteases.

We used a model of small intestine ischemia developed in mice by reversible occlusion of the superior mesenteric artery for 90 minutes, followed by 0,2 , or 5 hours of reperfusion. By combining pharmacological and gene-deletion approaches, we demonstrate here the pivotal role of serine proteases, through the activation of $\mathrm{PAR}_{1}$ and $\mathrm{PAR}_{2}$, in inflammatory damage associated with intestinal ischemia-reperfusion.

\section{Materials and Methods}

\section{Animals}

C57BI/6 male mice (8 weeks old) were obtained from Janvier (Le Genest Saint Isle, France). $P A R_{2}^{-{ }^{-1}}$ and wildtype littermates $\left(\mathrm{Par}_{2}{ }^{+/+}\right)$were originally provided by Johnson \& Johnson Pharmaceutical Research Institute. ${ }^{29,30}$ Animals were kept under pathogen-free conditions and were given free access to food and water. All of the experimental protocols were approved by local animal care and ethics committees and followed the guidelines of French Councils on Animal Care.

\section{Surgical Procedure and Treatments}

Mice were anesthetized with sodium pentobarbital (Pentobarbital sodique, Ceva Santé Animale, Libourne, France) (50 mg/kg intraperitoneally). After abdominal laparotomy, the small bowel was retracted to the left and the superior mesenteric artery was temporarily occluded using a microvascular clip to cause ischemia. After $90 \mathrm{~min}$ utes, the clip was gently removed, allowing reperfusion. Mice were sacrificed right after the ischemic period (time $0), 2$, or 5 hours after reperfusion. Sham-operated (SO) animals, in which abdominal laparotomy and artery isolation were performed without occlusion of the vessel, served as controls. After the surgical procedure, the midline incision of the abdominal wall was closed by two- layer sutures. After recovering from anesthesia, animals were returned to their cages. At the end of the experiments, animals were anesthetized with sodium pentobarbital to collect blood through cardiac puncture. Euthanasia was performed by cervical dislocation. Heparinized blood samples were centrifuged at $7500 \times g$ for 10 minutes to obtain plasma. For biochemical analysis, ileal tissue was excised and processed.

Mice were treated as follows: the serine protease inhibitor FUT-175 (10 mg/kg dissolved in saline; Santa Cruz Biotechnology, tebu-bio, Le Perray en Yvelines Cedex, France) was administered intravenously at the beginning of ischemia and repeated at the moment of reperfusion; the $\mathrm{PAR}_{1}$ antagonist $\mathrm{SCH}-79797$ (5 mg/kg dissolved in carboxymethylcellulose; Tocris Bioscience, Bristol, UK) was administered intraperitoneally twice, at 18 hours and 2 hours before the surgery. A similar surgical procedure was used for both the $\mathrm{Par}_{2}^{+/+}$and $\mathrm{Par}_{2}^{-1-}$ mice.

\section{Protease Activity Assay}

Trypsin-like proteolytic activity was measured both in intestinal tissue and plasma using a microplate reader NOVOstar (BMG Labtech, Champigny s/Marne, France). On sacrifice, plasma samples were collected and a piece of ileal tissue was excised and rinsed in $1 \times$ PBS to remove all intraluminal content and was then homogenized in $1 \mathrm{~mL}$ of $1 \times$ PBS (pH 7.2) with $1 \% \mathrm{NP}-40,0.5 \%$ sodium deoxycholate, $0.1 \%$ SDS using Precellys 24 homogenizer in Precellys lysing CK14 tubes (Bertin Technologies, Ozyme, France). The homogenized tissues were centrifuged at $5000 \times g$ for 5 minutes. The trypsinlike activity was measured using tosyl-Gly-Pro-Arg p-nitroanilide (150 $\mu \mathrm{mol} / \mathrm{L}$; Sigma, Saint Quentin Fallavier, France) as substrate in $100 \mathrm{mmol} / \mathrm{L} \mathrm{Tris} / \mathrm{HCl}, 1 \mathrm{mmol} / \mathrm{L}$ $\mathrm{CaCl}_{2}$ buffer $(\mathrm{pH}$ 8). The hydrolysis rate was measured at $37^{\circ} \mathrm{C}$ over a 30 -minute period in absorbance at $405 \mathrm{~nm} .{ }^{31}$ Activity was standardized to the rate generated by trypsin of known concentration from porcine pancreas (Sigma). Plasma activity was expressed as $\mathrm{U} / \mathrm{mL}$, whereas tissue activity was normalized to the homogenate protein concentrations determined with a BCA kit (Pierce, Thermo Scientific, Courtaboeuf, France) and expressed as U/mg protein. When required, protease inhibitors were added to tissue supernatants or plasma samples: E-64 10 $\mu \mathrm{mol} / \mathrm{L}$ (tebu-bio), Pepstatin A $1 \mu \mathrm{mol} / \mathrm{L}$ (Sigma), AESBF

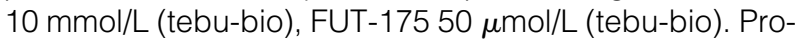
tease inhibitor doses were chosen according to previous data reported in the literature. ${ }^{32-37}$

\section{Myeloperoxidase Activity}

Myeloperoxidase (MPO) activity was measured as an index of granulocyte infiltration as previously described in ileal tissues harvested at the time of sacrifice. ${ }^{38}$ Briefly, ileal tissue samples were homogenized in a solution of $0.5 \%$ hexadecyltrimethylammonium bromide dissolved in phosphate buffer solution $(\mathrm{pH} 6)$ using Precellys 24 homogenizer in Precellys lysing CK14 tubes (Bertin Technologies). The homogenized tissues were centrifuged at $13,000 \times g$ for 5 minutes $\left(4^{\circ} \mathrm{C}\right)$, and the supernatants 
were placed on 96 well plates. Buffer, supplemented with $1 \%$ hydrogen peroxide/O-dianisidine dihydrochloride (Sigma), was added to each well. Optical density readings were taken for 1 minute at 30-second intervals at 450 nm using a microplate reader NOVOstar (BMG Labtech). Activity was normalized to the sample protein concentration determined with a BCA kit (Pierce) and expressed as $\mathrm{mU} / \mathrm{mg}$ protein.

\section{Chemokines Protein Expression}

lleal tissue samples harvested at the time of sacrifice were homogenized in $700 \mu \mathrm{L}$ of cell lysis buffer [20 $\mathrm{mmol} / \mathrm{L} \mathrm{Tris-HCl}(\mathrm{pH} 7.5), 150 \mathrm{mmol} / \mathrm{L} \mathrm{NaCl}, 1 \mathrm{mmol} / \mathrm{L}$ $\mathrm{Na}_{2}$ EDTA, 1 mmol/L EGTA, 1\% Triton X-100, $2.5 \mathrm{mmol} / \mathrm{L}$ sodium pyrophosphate, $1 \mathrm{mmol} / \mathrm{L} \beta$-glycerophosphate, 1 $\mathrm{mmol} / \mathrm{L} \mathrm{Na}_{3} \mathrm{VO}_{4}, 1 \mu \mathrm{g} / \mathrm{mL}$ leupeptin; Sigma] supplemented with antiprotease cocktail (SIGMAFAST; Sigma) using Precellys 24 homogenizer in Precellys lysing CK14 tubes (Bertin Technologies). After centrifugation (10,000 $\times$ g 10 minutes, $4^{\circ} \mathrm{C}$ ), supernatants were filtered on QIAshredder columns (Qiagen, Courtaboeuf Cedex, France). Fifty microliters of this homogenate were used for simultaneous measurement of keratinocyte chemoattractant (KC) and monocyte chemoattractant protein (MCP-1), using cytometric bead array on fluorescent cell sorter FACSCalibur, according to the manufacturer's instructions (BD Biosciences, Le Pont de Claix, France). ${ }^{39}$ Raw values were normalized to the sample protein concentration determined with a BCA kit (Pierce). Chemokine concentrations were extrapolated from standard curves with the help of FCAP Array software (Soft Flow, St. Louis Park, MN) and expressed as pg/mg protein. In accordance with the manufacturer's information, only values above the limit of cytokine detection were considered.

\section{Immunohistochemistry}

Samples of mouse small intestines were formalin fixed, embedded in paraffin, and cut into $5-\mu \mathrm{m}$ sections. To reveal antigenic motifs, slides were boiled for 40 minutes at $\mathrm{pH} 6$ after deparaffinization and incubated in sodium borohydride 1\% (Sigma) to remove autofluorescence. Slides were then washed three times in phosphate-buffered saline (PBS; Invitrogen, Cergy Pontoise, France) with $1 \%$ bovine serum albumin (Sigma) and $0.5 \%$ Triton $X-100$, and were incubated overnight with primary antibody directed against $\mathrm{PAR}_{1}$ (rabbit; AbCam, Paris, France), $\mathrm{PAR}_{2}$ (rabbit; Santa Cruz Biotechnology, tebubio), or CD45 (goat; R\&D Systems, Lille, France). ${ }^{40}$ After three washes with $1 \times$ PBS, slides were incubated with appropriate secondary antibody (Alexa Fluor 680, or Alexa Fluor 555; Invitrogen) for 30 minutes. Slides were mounted with Prolong (Invitrogen), and intestinal samples were visualized using a Zeiss 710 Meta confocal fluorescence microscope (Le Pecq, France) with a $\times 20$ or $\times 63$ objective. ${ }^{41}$

\section{Survival Rates}

The survival rates in each group were monitored from the beginning of the surgery to the end of the reperfusion times.

\section{Western Blot Analysis}

Western blot analysis was performed on ileal samples collected from SO animals and mice subjected to 90 minutes of ischemia followed by 2 hours of reperfusion. Proteins were extracted by homogenizing the tissues in 1 $\mathrm{mL}$ of $1 \times$ PBS $(\mathrm{pH} 7.2)$ with $1 \% \mathrm{NP}-40,0.5 \%$ sodium deoxycholate, $0.1 \%$ SDS, supplemented with antiprotease cocktail (SIGMAFAST; Sigma), using Precellys 24 homogenizer in Precellys lysing CK14 tubes (Bertin Technologies). The homogenized tissues were centrifuged at $5000 \times g$ for 5 minutes. Samples were normalized for total protein concentration using the BCA kit (Pierce) and resuspended in Laemmli buffer (Bio-Rad, Marnes-la-Coquette, France). Proteins ( $40 \mu \mathrm{g} / 30 \mu \mathrm{L}$ ) were resolved by SDS-polyacrylamide gel electrophoresis on $8 \%$ gels and were transferred to nitrocellulose membranes (Bio-Rad). The membranes were probed with antibodies against actin (ab1801, 1:1000; Abcam, Paris, France), trypsin (sc-67388, 1:200; Santa Cruz Biotechnology, Heidelberg, Germany), intracellular adhesion molecule 1 (ICAM-1) (sc-1511; Santa Cruz Biotechnology), vascular cell adhesion molecule I (VCAM-1) (sc-1504; Santa Cruz Biotechnology), and $\alpha-2$ macroglobulin ( $\alpha$-2M) (sc-28870; Santa Cruz Biotechnology). Western blots were probed with donkey anti-goat secondary antibody conjugated to IRdye 800 (1:1000; LI-COR, Cergy-Pontoise-Cedex, France) and donkey anti-rabbit Alexa Fluor 555 (Invitrogen). Blotted proteins were detected and quantified using the Odyssey infrared imaging system (LI-COR NE).

\section{Statistical Analysis}

Data are presented as mean \pm SEM. Analyses were performed using GraphPad Prism 5 software (GraphPad Software, La Jolla, CA). All data were normally distributed. Between-group comparisons were performed by Student's unpaired 2-tailed t-test. Multiple comparisons for within group I-R were performed by repeatedmeasures one-way analysis of variance followed by Tukey's procedure. Statistical significance was accepted at $P \leq 0.05$.

\section{Results}

\section{Intestinal Ischemia-Reperfusion Injury Is Associated with Protease Release}

Intestinal I-R caused inflammation to ischemic tissues as observed by increased intestinal MPO activity, a marker of granulocyte infiltration, and mortality (Figure 1, A and B). Specifically, superior mesenteric artery occlusion without reperfusion period (OhR) did not significantly increase MPO activity. However, 90 minutes of ischemia 

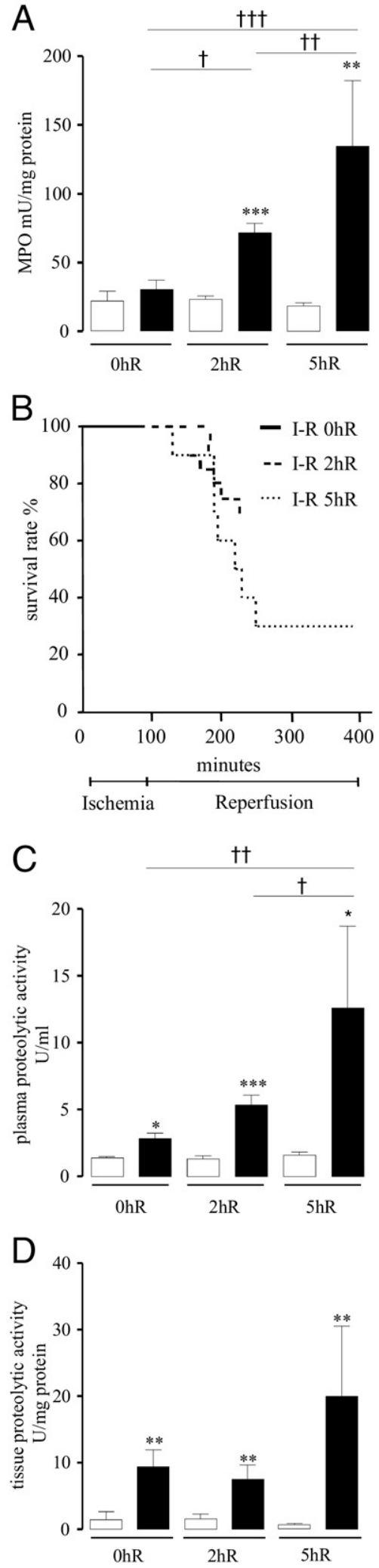

Figure 1. Effects of 90 minutes of ischemia followed by different times of reperfusion (0 hours, 2 hours, 5 hours) on intestinal MPO activity (A), survival rate $(\mathbf{B})$, plasma protease activity $(\mathbf{C})$, and tissue protease activity $(\mathbf{D})$ in sham-operated (SO) (white bars) or I-R (black bars) mice. In B, SO groups showed $100 \%$ survival rate (data not shown). In A, C, and D, data represent means \pm SEM of 8 to 12 animals per group. ${ }^{*} P \leq 0.05$, ${ }^{* * *} P \leq 0.01$, and ${ }_{* * * * *} P \leq 0.001$ versus the corresponding SO group; ${ }^{\dagger} P \leq 0.05,{ }^{\dagger} P \leq 0.01$, and ${ }^{+t} P \leq 0.001$ versus the indicated I-R group. followed by 2 hours (2hR) or 5 hours (5hR) of reperfusion caused a significant increase in MPO activity, compared to the corresponding SO group $(71.6 \pm 6.9$ versus $23.4 \pm$ $2.3 \mathrm{mU} / \mathrm{mg}$ protein, $P \leq 0.001$, and $134.1 \pm 48.1$ versus $18.0 \pm 2.7 \mathrm{mU} / \mathrm{mg}$ protein, $P \leq 0.01)($ Figure $1 \mathrm{~A})$. The experimental condition of ischemia alone allowed $100 \%$ animal survival rate. Mortality only appeared after reperfusion, and its rate increased with time of reperfusion (I-R $2 \mathrm{hR} 25 \%$ and I-R 5hR 70\%) (Figure 1B). We investigated trypsin-like proteolytic activity balance associated with intestinal ischemic insult in ileal tissues and in plasma, by measuring the hydrolysis of the substrate tosyl-Gly-Pro$\operatorname{Arg} p$-nitroanilide. Proteolytic activity released in plasma after 90 minutes of ischemia (OhR) was twofold higher than the activity in the corresponding SO group (2.8 \pm 0.4 versus $1.4 \pm 0.11 \mathrm{U} / \mathrm{mL}, P \leq 0.05)$. This increase was not only maintained, but also further enhanced after reperfusion, compared to $\mathrm{SO}$ group (2hR $5.3 \pm 0.74$ versus $1.3 \pm 0.26 \mathrm{U} / \mathrm{mL}, P \leq 0.001$ and $5 \mathrm{hR} 12.5 \pm 6.2$ versus $1.5 \pm 0.24 \mathrm{U} / \mathrm{mL}, P \leq 0.05$ ) (Figure $1 \mathrm{C}$ ). Similarly, ischemia caused a significant increase of tissue proteolytic activity ( $9.4 \pm 2.56$ versus $0.9 \pm 1.4 \mathrm{U} / \mathrm{mL}, P \leq 0.01)$, and this activity was significantly maintained after 2 and 5 hours of reperfusion compared to the corresponding SO group $(7.4 \pm 2.2$ versus $1.5 \pm 0.7 \mathrm{U} / \mathrm{mL}, P \leq 0.01$ and $19.9 \pm 10.6$ versus $1.4 \pm 0.7 \mathrm{U} / \mathrm{mL}, P \leq 0.01$ ) (Figure 1D). These findings show that ischemia, as well as reperfusion, is associated with an intense release of proteolytic activity (directed at an arginine site), both within ischemic tissues and in plasma.

\section{Serine Proteases Are the Major Proteases Dosed in Plasma and Ischemic Tissues on Ischemia-Reperfusion Injury}

To identify the proteases responsible for increasing proteolytic activity during I-R, different specific protease inhibitors were incubated in vitro (20 minutes at room temperature) with tissue homogenates or plasma samples from animals subjected to 90 minutes of ischemia, followed by 2 hours of reperfusion. Proteolytic activity assay using the same substrate as in Figure 1 was then performed on those samples.

Cysteine protease inhibitor E-64 (10 $\mu \mathrm{mol} / \mathrm{L})$ and aspartate proteases inhibitor Pepstatin A ( $1 \mu \mathrm{mol} / \mathrm{L})$ significantly reduced plasma proteolytic activity respectively to $23 \%$ and $34 \%$ (Figure 2A), whereas the same inhibitors did not affect tissue proteolytic activity (Figure 2B), even when tested at 100 and 1000 times higher concentrations (data not shown). These data suggest that cysteine and aspartate proteases are most likely not responsible for the proteolytic activity measured in tissues after I-R, whereas in plasma, some cysteine and aspartate proteases are active after I-R. Incubation with two different serine protease inhibitors, compound FUT-175 (50 $\mu \mathrm{mol} / \mathrm{L})$ and AEBSF ( $10 \mathrm{mmol} / \mathrm{L})$, almost completely abolished the proteolytic activity induced by I-R both in intestinal tissue (87\% for AESBF and 94\% for FUT-175) and plasma samples (respectively, 93\% and 96\%) (Figure 2, $A$ and $B$ ). 
A

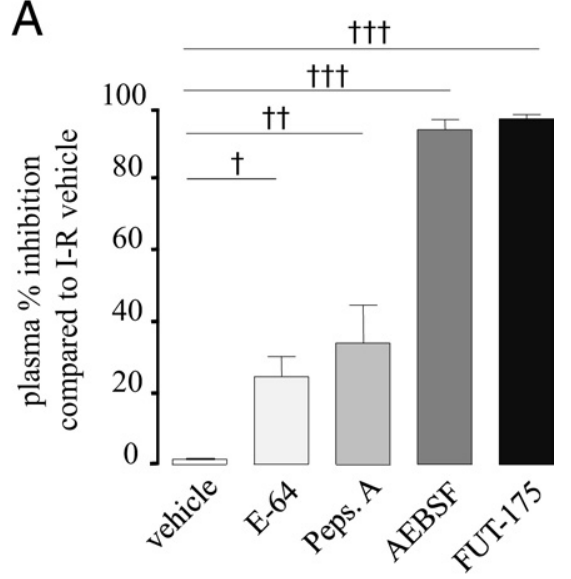

B

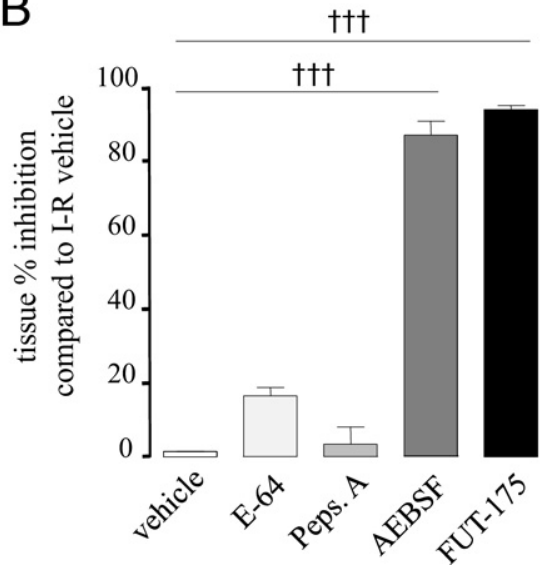

Figure 2. Effects on proteolytic activity of the addition of specific protease inhibitors to samples collected from plasma (A) and intestinal tissue (B) Different protease inhibitors (E-64 $10 \mu \mathrm{mol} / \mathrm{L}$, Pepstatin A $1 \mu \mathrm{mol} / \mathrm{L}, \mathrm{AESBF}$ $10 \mathrm{mmol} / \mathrm{L}$, and FUT-175 $50 \mu \mathrm{mol} / \mathrm{L}$ ) were incubated 20 minutes at room temperature with plasma samples or tissue homogenates from animals subjected to ischemia followed by 2 hours of reperfusion. Proteolytic activity was then performed on those samples using tosyl-Gly-Pro-Arg $p$-nitroanilide as substrate. Data represent means \pm SEM of 8 to 12 animals per group. ${ }^{\dagger} P \leq$ $0.05,{ }^{t} P \leq 0.01,{ }^{\dagger t} P \leq 0.001$ versus vehicle.

Taken together, these data suggest that the argininedirected proteolytic activity detected during I-R injury in tissues and in plasma was, for the most part, due to serine proteases.

\section{Serine Protease Inhibitor Prevents Intestinal Ischemia-Reperfusion Injury}

Based on these results, we then investigated in vivo the effects of serine protease inhibition in the I-R model by injecting, intravenously, the serine protease inhibitor FUT175 (10 mg/kg in saline) at the moment of ischemia and at the beginning of the 2-hour reperfusion period.

Systemic treatment with FUT-175 did not significantly reduce the level of proteolytic activity in plasma (Figure $3 \mathrm{~A}$ ), but completely abolished tissue proteolytic activity $(0.35 \pm 0.1$ versus $4.5 \pm 1.2 \mathrm{U} / \mathrm{mg}$ protein, $P \leq 0.01$; Figure 3B) released after I-R. Interestingly, basal proteolytic activity in plasma of SO groups was significantly reduced by FUT-175 treatment $(1.3 \pm 0.2$ versus $0.4 \pm$
$0.1 \mathrm{U} / \mathrm{mL}, P \leq 0.05$; Figure $3 \mathrm{~A}$ ). Systemic treatment with the serine protease inhibitor FUT-175, significantly decreased granulocyte recruitment induced by $\mathrm{I}-\mathrm{R}$, as observed by reduced intestinal MPO activity (74.6 \pm 6.9 versus $40.6 \pm 3.7 \mathrm{mU} / \mathrm{mg}$ protein, $P \leq 0.01$, Figure $3 \mathrm{C}$ ). In addition, the survival rate was significantly increased in FUT-175-treated mice, compared to I-R saline group (71\% versus 95\%, $P \leq 0.05$; Figure 3D).

Because serine protease inhibition significantly decreased leukocyte recruitment to ischemic and reperfused tissues, the possibility that this lack of inflammatory cell recruitment was due to deficient expression of chemokines or adhesion molecules was investigated. I-R markedly increased $\mathrm{KC}$ and MCP-1 intestinal concentrations compared to the sham-operated group. The treatment of mice submitted to I-R with FUT-175 significantly reduced the expression of both $\mathrm{KC}$ and $\mathrm{MCP}-1$ in jejunal tissues, compared to vehicle-treated mice (KC: $31.1 \pm$ 4.7 versus $59.3 \pm 10.1, P \leq 0.05$, and MCP-1: $89.4 \pm$ 15.3 versus $181.3 \pm 37.9, P \leq 0.05$ ) (Figure $3, \mathrm{E}$ and $\mathrm{F}$ ). $\mathrm{I}-\mathrm{R}$ also modulated the expression of endothelial adhesion molecules such as ICAM and VCAM. The expression levels of both ICAM-1 and VCAM-1 were increased in the I-R group compared to SO mice; the treatment with FUT175 significantly decreased the expression of both ICAM-1 and VCAM-1 in I-R intestinal tissue, compared to $\mathrm{I}-\mathrm{R}$ vehicle-treated mice (Figure 3, $\mathrm{G}$ and $\mathrm{H}$ ).

These data demonstrate that the administration of a serine protease inhibitor at the moment of ischemia and at the beginning of reperfusion protects from granulocyte infiltration into tissues, through the reduction of chemokine protein expression and through a down-regulation of adhesion molecules.

\section{$P A R_{1}$ and $P A R_{2}$ Expression in the Mouse Small Intestine}

As shown in Figure 4, $\mathrm{PAR}_{1}$ was weakly expressed in the mucosa of mouse small intestine: faintly in cells at the base of villi, and clearly on blood vessels. In contrast, $\mathrm{PAR}_{2}$ was strongly detected in epithelial cells and colocalized with $88.1 \%$ of CD45-positive cells, whereas PAR did not colocalize with the CD45 marker in the small intestine. The surgical procedure (SO animals) and the condition of ischemia alone or ischemia followed by 2 hours of reperfusion did not change the pattern of cell types expressing $\mathrm{PAR}_{1}$ and $\mathrm{PAR}_{2}$ (not shown).

\section{Ischemia-Reperfusion-Induced Granulocyte Recruitment Is $P A R_{1}$ and $P A R_{2}$ Dependent}

As shown in Figure 5, A and B, neither the intraperitoneal administration of a selective $\mathrm{PAR}_{1}$ antagonist (compound $\mathrm{SCH}-79797,5 \mathrm{mg} / \mathrm{kg}$ in carboxymethylcellulose), nor $\mathrm{PAR}_{2}$ deficiency, modified plasma and tissue proteolytic activity induced by 90 minutes of ischemia followed by 2 hours of reperfusion, compared to I-R vehicle. However, $\mathrm{SCH}-79797$ treatment and $\mathrm{PAR}_{2}$ deficiency caused a significant decrease in MPO activity (40.58 \pm 6.4 versus $89.5 \pm 13.8 \mathrm{mU} / \mathrm{mg}$ protein, $P \leq 0.05$, and $65.0 \pm 8.0$ 
A

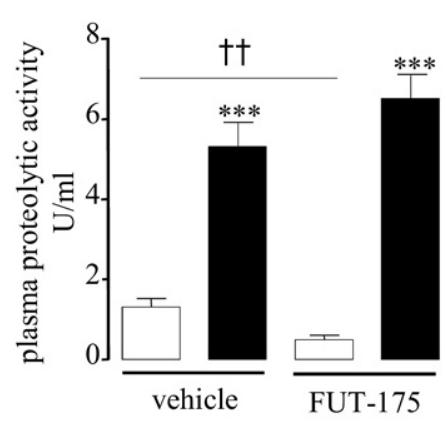

D

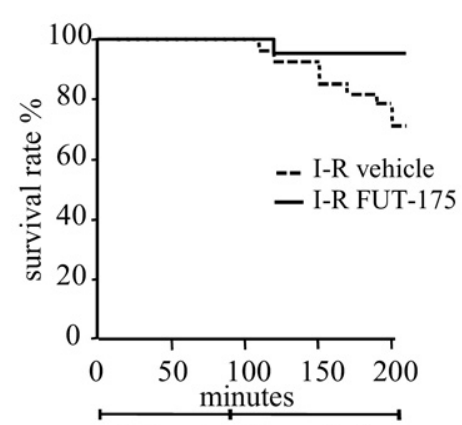

B

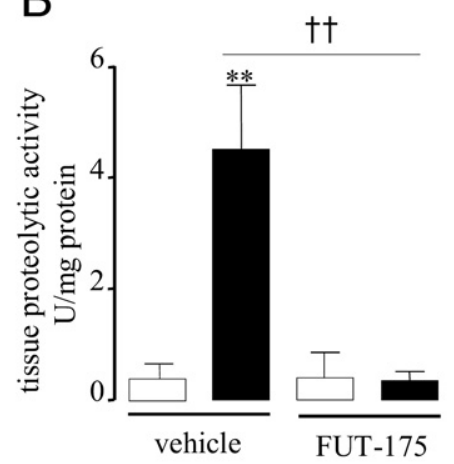

E

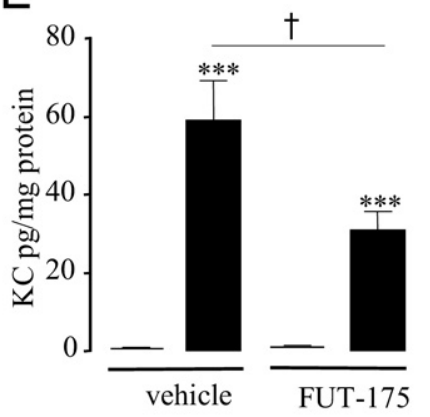

C

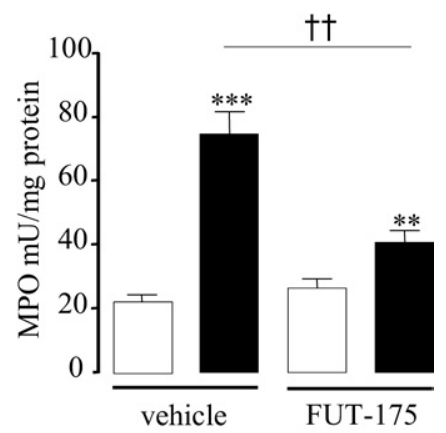

$\mathrm{F}$

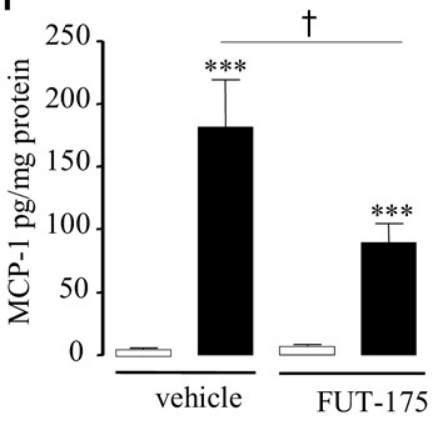

Ischemia Reperfusion
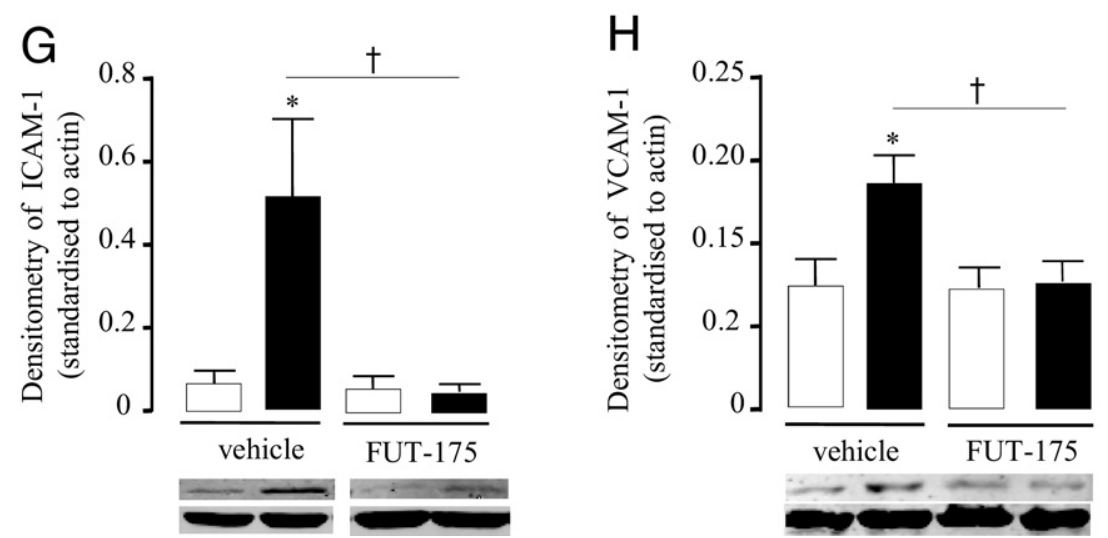

Figure 3. In vivo effects of systemic treatment with the serine protease inhibitor FUT-175 (10 mg/kg i.v.) on proteolytic activity dosed in plasma (A) and in intestinal tissue (B), on MPO activity $(\mathbf{C})$, survival rate $(\mathbf{D})$, chemokine (KC and MCP-1) protein expression (E and F), and adhesion molecules (ICAM-1 and VCAM-1) ( $\mathbf{G}$ and $\mathbf{H}$ ). Sham-operated (SO) group is represented by white bars and I-R group ( 90 minutes +2 hours reperfusion) by black bars. Data in A, B, C, $\mathrm{E}$, and $\mathrm{F}$ represent means \pm SEM of 8 to 12 animals per group. ${ }^{* * *} P \leq 0.01,{ }^{* * * * *} P \leq 0.001$ versus the corresponding SO group; ${ }^{\dagger} P \leq 0.05,{ }^{\dagger t} P \leq 0.01$ versus the indicated I-R group.

versus $106.8 \pm 12.7 \mathrm{mU} / \mathrm{mg}$ protein, $P \leq 0.05$; Figure 5 , $C$ and $D)$ and significantly reduced the levels of both ICAM-1 and VCAM-1 (Figure 5, E, F, G, and H) in I-R mice, compared to the vehicle I-R group and I-R Par ${ }_{2}{ }^{+/+}$ mice (Figure 5, C and D). Interestingly, I-R mice treated with the $\mathrm{PAR}_{1}$ antagonist $\mathrm{SCH}-79797$ (KC: $33.9 \pm 6.4$ versus $79.1 \pm 14.7, P \leq 0.05$, and MCP-1: $76,5 \pm 11.6$ versus $140.5 \pm 26.8 ; P \leq 0.05$; Figure 5 , I and J), but not I-R PAR 2 -deficient mice (KC: $73.6 \pm 26.6$ versus $73.2 \pm$ 26.3 and MCP-1: $145.3 \pm 54.9$ versus $245.1 \pm 92.1$; Figure $5, \mathrm{~K}$ and $\mathrm{L}$ ) showed a significant reduction in protein expression levels of both $\mathrm{KC}$ and MCP-1 compared to I-R vehicle and I-R $\mathrm{Par}_{2}{ }^{+/+}$mice. These findings suggest that serine protease release induced by I-R oc- curred independently of $\mathrm{PAR}_{1}$ or $\mathrm{PAR}_{2}$ activation, but both receptors contribute to post-ischemic intestinal neutrophil recruitment, although through distinct mechanisms involving differential regulation of adhesion molecules or chemokine expression.

\section{Ischemia-Reperfusion Induces Trypsin and Decreases $\alpha$-2M Expression in Ileal Tissue}

Levels of the serine protease trypsin, thrombin, plasmin, and chymotrypsin were measured using Western blotting technique in ileal tissues of SO mice and mice subjected to 90 minutes of ischemia alone or followed by 2 hours of 

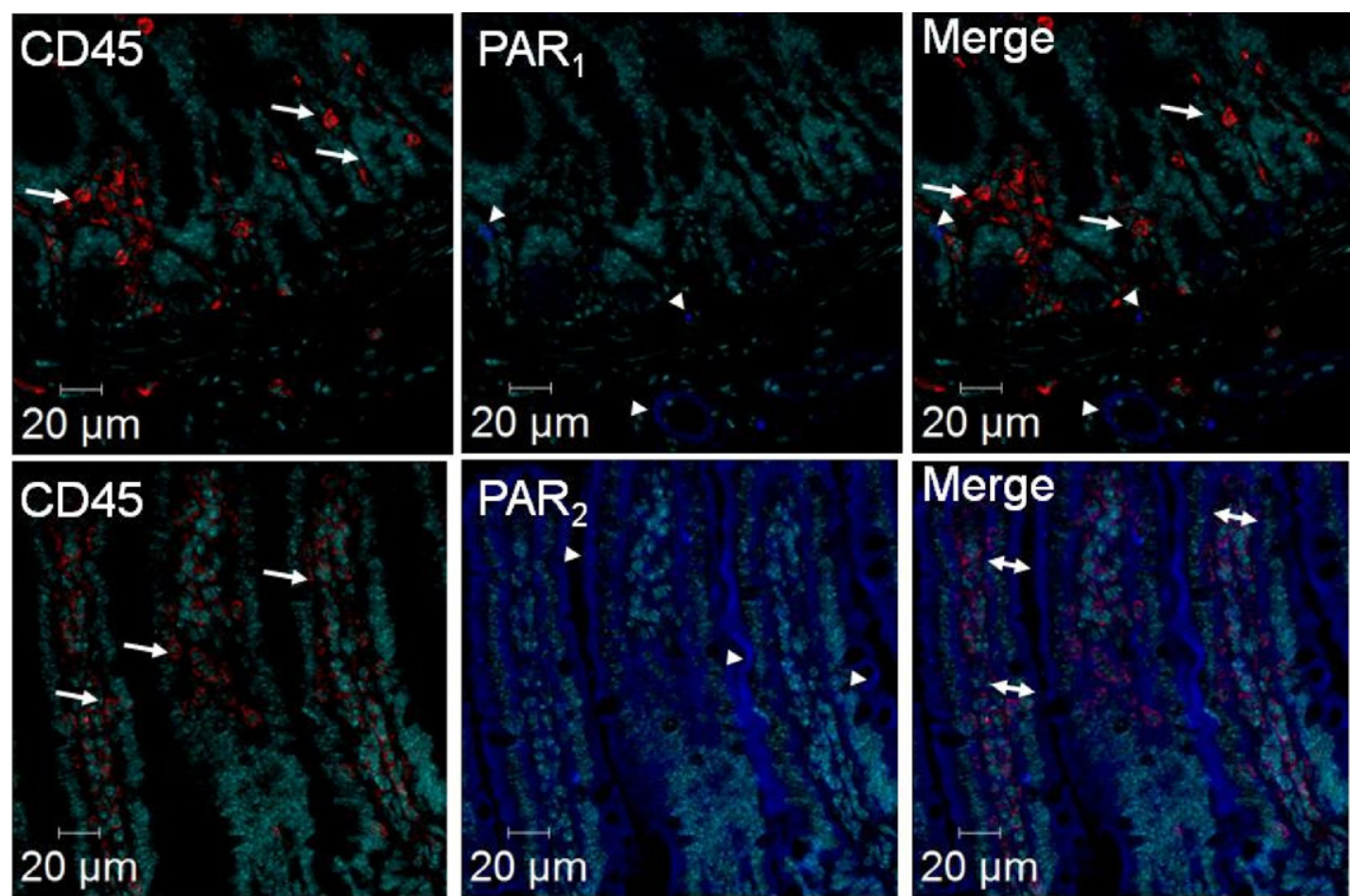

Figure 4. $\mathrm{PAR}_{1}$ and $\mathrm{PAR}_{2}$ protein expression in mouse small intestine detected by immunohistochemistry. Upper panels: anti- $P A R_{1}$ antibody (blue) and anti-CD 45 antibody, an immune cell marker (red) staining; Lower panels: anti-PAR 2 antibody (blue) and anti-CD 45 antibody (red) staining. Arrowheads showed $\mathrm{PAR}_{1}$ and $\mathrm{PAR}_{2}$ staining, respectively, in the upper and lower panels. Arrows indicate CD 45 staining, and double arrows indicate colocalization of CD 45 and $\mathrm{PAR}_{2}$.

reperfusion (Figure 6A). In tissues after ischemia alone or $\mathrm{I}-\mathrm{R}$, the protein levels of $25-\mathrm{kDa}$ trypsin were significantly higher compared to SO mice. A trypsin 32-kDa isoform was also detected in intestinal tissues from I-R animals (data not shown). The treatment with FUT-175 did not modify trypsin expression in I-R mice (data not shown). Thrombin, plasmin, and chymotrypsin were not detected in intestinal tissues, whether mice were SO or subjected to I-R. Finally, no difference in plasma levels of trypsin was found between I-R and SO mice (data not shown). Levels of the pan-proteinase inhibitor $\alpha$-2M were measured using Western blotting technique. As shown in Figure 6B, the $\alpha-2 \mathrm{M}$ tissue levels were reduced after 90 minutes of ischemia and significantly decreased by 2 hours of reperfusion after the ischemic period. No difference in plasma levels of $\alpha-2 \mathrm{M}$ was found between I-R and SO mice (data not shown).

\section{Discussion}

In the present study, we provide evidence of a significant increase of serine protease activity in mouse plasma and ileal samples as a consequence of intestinal I-R injury. We also provide experimental evidence that this proteolytic activity plays an important role in the lethality and inflammatory response characterized by granulocyte recruitment to ischemic tissues. This effect appears to be mediated through the activation of $\mathrm{PAR}_{1}$ and $\mathrm{PAR}_{2}$. Trypsin, which was found to be up-regulated in tissues just after the ischemic period and which can activate both $P A R_{2}$ and $P A R_{1}$, could be the protease responsible for the IRI-associated PAR-dependent granulocyte recruitment.

Our results not only provide definitive insights into the pathogenetic role for arginine-specific cleavage proteoIytic activity in intestinal IRI, but also point to the importance of proteases during the hypoxic period. Ischemia alone clearly increased proteolytic activity both in tissues and in plasma, demonstrating that this activity is thus not directly linked to the release of proteases from inflammatory cells, which infiltrate the tissues solely during reperfusion. Tissue proteolytic activity was maintained significantly higher, and it was further increased in plasma after 2 hours of reoxygenation after intestinal hypoxia. During that period, it is possible that proteolytic activity is increased by the release of infiltrated inflammatory cells proteases. If this is the case, a different pattern of proteases might be released during ischemia, versus reperfusion. Our results also showed that the expression of the pan-proteinase inhibitor $\alpha$-2 macroglobulin was significantly reduced in intestinal tissues after 2-hour reperfusion, but not after ischemia only, suggesting again that the type of active proteases during ischemia and during reperfusion might be different. However, one cannot rule out that common proteases are produced during ischemia and reperfusion periods. Indeed, we found that trypsin expression was up-regulated in intestinal tissues both after ischemia and after 2 hours of reperfusion (Figure 6). Above all, we provide evidence here that the inhibition of tissue protease activity during the ischemic 
A

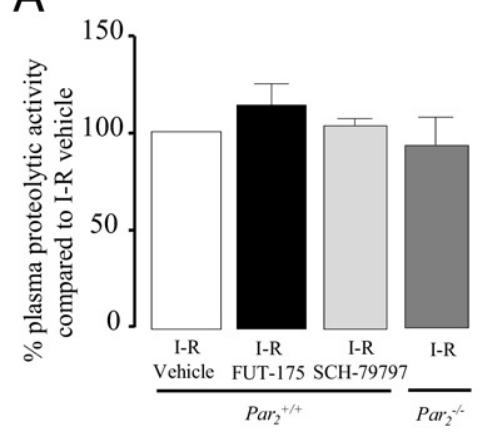

D

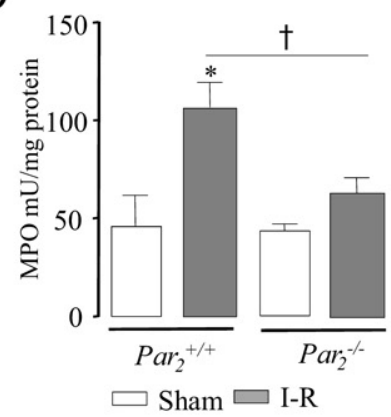

$\mathrm{G}$

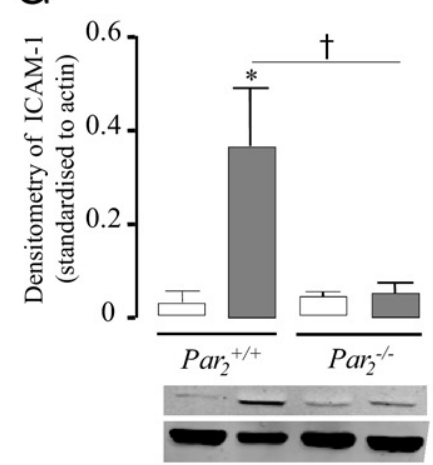

$\mathrm{J}$

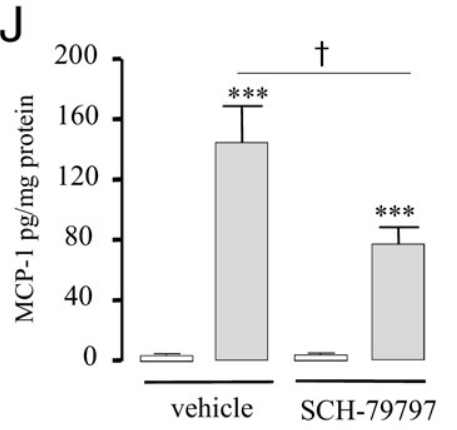

B

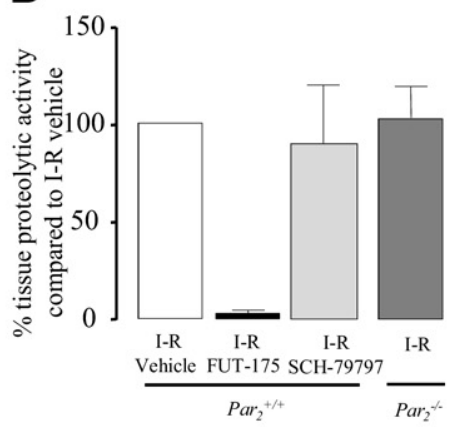

E

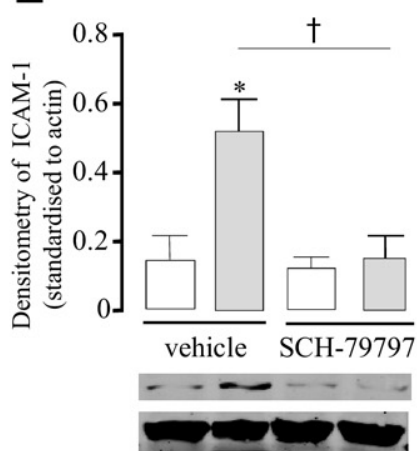

$\mathrm{H}$

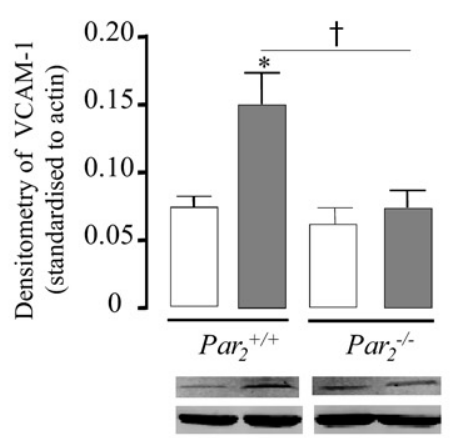

K

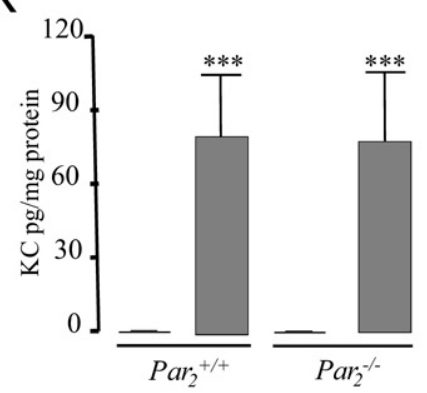

C

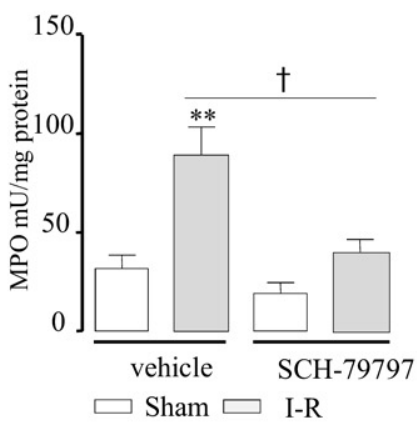

$\mathrm{F}$

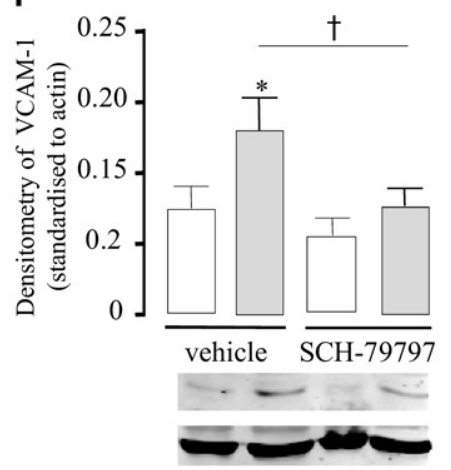

I

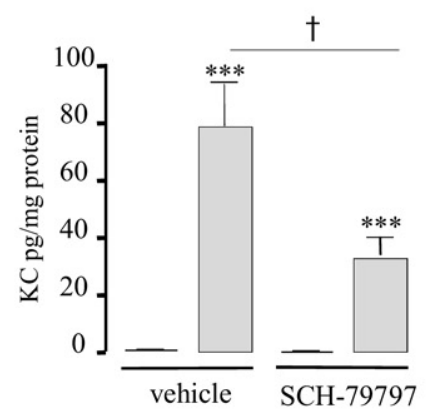

$\mathrm{L}$

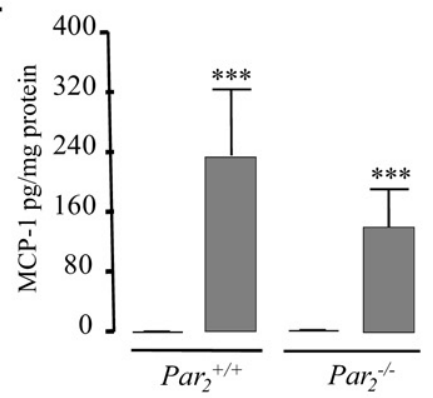

Figure 5. In A and $B$, effects of treatment with the $\mathrm{PAR}_{1}$ antagonist $\mathrm{SCH}-79797$ (5 mg/kg i.p.), effects of $\mathrm{PAR}_{2}$ deficiency $\left(P a r_{2}{ }^{-1}\right)$, and effects of treatment with the serine protease inhibitor FUT-175 in I-R mice ( 90 minutes +2 hours reperfusion), compared, respectively, to vehicle or littermate mice ( $\left.P a r_{2}^{+/+}\right)$. Effects of treatment with the PAR 1 antagonist SCH-79797 and effects of PAR deficiency (Par2 ${ }^{-1}$ ) on MPO activity in sham-operated (SO) or I-R mice (C and D), chemokines (KC and MCP-1) protein expression $(\mathbf{E}, \mathbf{F}, \mathbf{G}$, and $\mathbf{H})$ and adhesion molecules (ICAM-1 and VCAM-1) $(\mathbf{I}, \mathbf{J}, \mathbf{K}$, and $\mathbf{L})$ compared to vehicle or littermate mice $\left(P a r_{2}{ }^{+/+}\right)$. Data represent means \pm SEM of 8 to 12 animals per group. ${ }^{*} P \leq 0.05,{ }^{* * *} P \leq 0.01$ versus the corresponding sham group); ${ }^{\dagger} P \leq 0.05$ versus the indicated I-R group.

period is important to prevent post-ischemic intestinal granulocyte recruitment. The compound FUT-175, a synthetic inhibitor of "trypsin-like" serine proteases such as factor VIla, factor XIla, kallikrein, thrombin, plasmin, tryp- sin, and tryptase ${ }^{42}$ administered just before ischemia and at the beginning of the reperfusion period significantly reduced intestinal MPO and tissue proteolytic activity. In contrast, a single administration of FUT-175 performed 

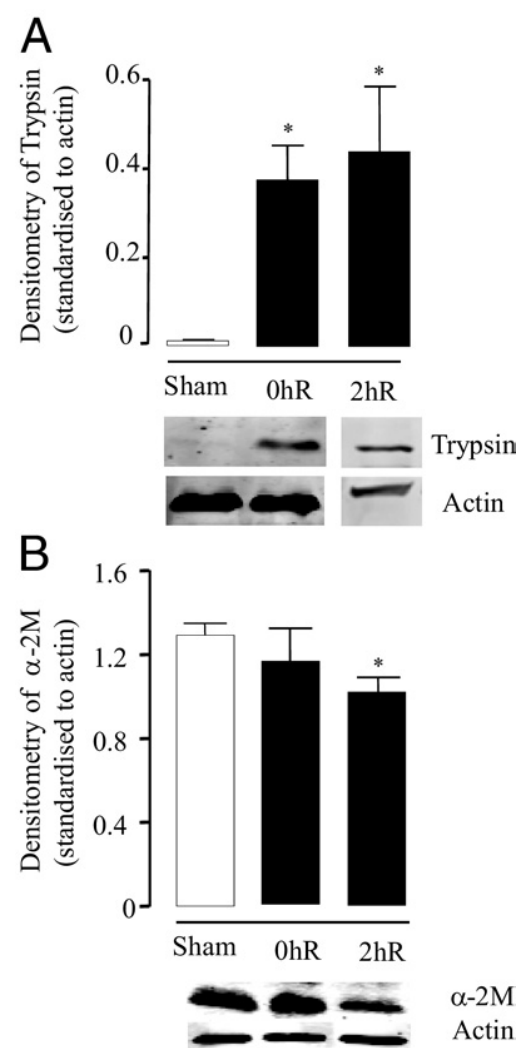

Figure 6. Protein expression of trypsin (A) and $\alpha-2$ macroglobulin $(\alpha-2 \mathrm{M})$ (B) measured by Western blot analysis in ileal tissue obtained from mice subjected to 90 minutes of ischemia alone (without reperfusion) (OhR) or mice subjected to ischemia followed by 2 hours of reperfusion, compared to sham-operated (SO) mice. SO group is represented by white bars and I-R group by black bars. The densitometry data of bands obtained by Western blot analysis is shown as a bar graph and represents means \pm SEM of six to eight animals per group. All densitometry readings are standardized to actin. ${ }^{*} P \leq 0.05$ versus the corresponding sham group.

either at the moment of ischemia or at the beginning of the reperfusion period did not show the same protective effects on intestinal granulocyte infiltration (data not shown).

The inflammatory leukocyte recruitment is first set by the release of chemokines, such as KC and MCP-1, which act as chemoattractants to guide the migration of white blood cells to the site of ischemia. ${ }^{43}$ Complex interactions between leukocytes and endothelium at the site of injury then lead to the rolling, adhesion, and transmigration of leukocytes, through processes involving various adhesion molecules expressed on the endothelium (such as ICAM and VCAM), and integrins expressed on immune cells. We showed that treatment with the largespectrum serine protease inhibitor FUT-175 significantly reduced intestinal granulocyte recruitment after I-R and concomitantly decreased the expression levels of chemokines KC and MCP-1, as well as adhesion molecules ICAM-1 and VCAM-1. Our data thus provide insights into the mechanisms by which proteases might induce granulocyte recruitment on intestinal I-R. Proteases seem to be able to regulate both the chemoattractant signal and the leukocyte/endothelium adhesion molecule signals.
Our results showed a proteolytic balance in plasma and intestinal tissues disrupted toward an increased proteolytic activity after intestinal IRI. This can be due to the increased expression of proteases, but also to the decreased expression of protease inhibitors. As a matter of fact, we show here that the $25-\mathrm{kDa}$ trypsin content was significantly higher in I-R tissue, compared to SO, thereby feeding the concept that some proteases are up-regulated after IRI. Trypsin could derive from pancreatic source and then enter intestinal tissues through the damaged epithelial barrier, but we cannot exclude that, as already reported, trypsin could be generated directly from epithelial or endothelial cells subjected to pathological stimuli. ${ }^{44-46}$ The proteolytic imbalance observed during reperfusion could also be due, at least in part, to the inactivation of endogenous protease inhibitors. It has been established that oxidants, massively produced during reperfusion, can inactivate physiological antiproteases. ${ }^{47-51}$ Our study showed decreased intestinal levels of $\alpha-2 \mathrm{M}$, a well-known pan-protease inhibitor, after IRI compared to the sham-operated group. Endogenous protease inhibitors are important protective mechanisms against the potential deleterious effects of proteases, and the decreased expression or inhibition of $\alpha-2 \mathrm{M}$ or other inhibitors such as antithrombin III (coagulation system), $\alpha 2$-antiplasmin (fibrinolytic system) could also be responsible for the disrupted proteolytic activity observed on intestinal ischemia-reperfusion. ${ }^{52,53}$

Intestinal I-R not only damage gut tissues, but also causes distant organ failure, rapidly leading to death. Compromised cardiac functions have been reported as the major cause of lethality in the intestinal I-R model. ${ }^{54}$ Since we report here that intravenous administration of the protease inhibitor FUT-175 strongly inhibited mortality in that model, it can be speculated that proteases are involved in mechanisms leading to cardiac failure. Indeed, it was reported that myocardial depressant factor (MDF) is released through the proteolytic action of serine proteases. ${ }^{55}$ Treatment with FUT-175 could inhibit some of the proteases responsible for the release of MDF, thereby decreasing MDF-related cardiac failure mortality. Interestingly, we observed that neither $\mathrm{PAR}_{1}$ antagonist nor $\mathrm{PAR}_{2}$ depletion was able to significantly inhibit intestinal I-R-induced mortality (data not shown), suggesting that the systemic consequences of intestinal I-R, possibly on multiple organ failure, occur independently of $\mathrm{PAR}_{1}$ or $\mathrm{PAR}_{2}$ activation. Regardless of its causes, restoration of the proteolytic unbalance by administration of a broad, large-spectrum serine protease inhibitor such as FUT175 has been shown to be therapeutically useful in our model of intestinal IRI in mice.

Using different proteases inhibitors in vitro, we showed that arginine-directed proteolytic activity detected during $\mathrm{I}-\mathrm{R}$ injury in tissues and in plasma was, for the most part, due to serine proteases. However, the profile of proteases dosed in plasma versus intestinal tissues seems to be slightly different, with a significant activity of cysteine and aspartate proteases detected in plasma, whereas those levels were not significant in intestinal tissues. The in vivo approach aiming at inhibiting argininecleavage proteolytic activity demonstrated that inhibition 
of this activity in plasma was not necessary to obtain a significant protection against lethality or inflammation, whereas inhibition of proteolytic activity in intestinal tissues by FUT-175 treatment was associated with protective effects. This demonstrates that tissue protease activity more than plasma activity is crucial for the dramatic issue of intestinal IRI.

This study indicates that endogenous proteases regulate the post-ischemic granulocyte recruitment. Over the most recent years, a number of studies have demonstrated that the proinflammatory effects of proteases, and particularly serine proteases, are mediated, in large part, by the activation of PARs. ${ }^{8}$ We showed by immunohistochemistry that in mouse small intestine, $\mathrm{PAR}_{1}$ is mostly expressed on blood vessels and weakly expressed in other cell types, whereas $\mathrm{PAR}_{2}$ is expressed on epithelial, endothelial, and immune intestinal cells. Mice treated with the $\mathrm{PAR}_{1}$ antagonist $\mathrm{SCH}-79797$ or $\mathrm{Par}_{2}{ }^{-/-}$phenotype mice submitted to ischemia followed by 2 hours of reperfusion were protected from the post-ischemic granulocyte recruitment. Logically, in those mice, although the inflammation was reduced, the proteolytic activity levels in plasma and tissues were still significantly elevated. These data suggest that both $\mathrm{PAR}_{1}$ and $\mathrm{PAR}_{2}$ could be responsible for the proinflammatory effects of proteases in this model, having a primary role in the recruitment of granulocytes. Indeed, various in vitro experiments have shown up-regulated levels of adhesion molecules on $\mathrm{PAR}_{1}$ or $\mathrm{PAR}_{2}$ activation on endothelial cells. $\mathrm{PAR}_{1}$ and $\mathrm{PAR}_{2}$ also regulate the release of chemokines such as IL-8 from gut epithelial cells in vitro ${ }^{56,57}$ Here, we demonstrated that $\mathrm{PAR}_{1}$ blockade caused a significant decrease in adhesion molecules (ICAM-1 and VCAM- 1 ) and in chemokine expression (KC and MCP-1) compared to the I-R vehicle group. The effects of $\mathrm{PAR}_{1}$ blockade were thus similar to the effects of protease inhibition by FUT175 (Figure 3), suggesting that these effects of proteases on adhesion molecules and chemokine expression might be mediated, at least in part, by $\mathrm{PAR}_{1}$ activation. $\mathrm{PAR}_{2}$ activation might also be implicated in the protease-induced adhesion molecule expression, but the fact that $\mathrm{PAR}_{2}$ deficiency failed to modify the increased expression of KC and MCP-1 showed that the regulation of the expression of those two chemokines by proteases is not a PAR ${ }_{2}$-dependent mechanism. $\mathrm{PAR}_{1}$ and $\mathrm{PAR}_{2}$ are both expressed on endothelial cells where they are known to induce adhesion molecule expression. ${ }^{58-61}$ Indeed, our results demonstrated a common role for $\mathrm{PAR}_{1}$ and $\mathrm{PAR}_{2}$ in inducing ICAM-1 and VCAM-1 overexpression on ischemia-reperfusion, facilitating granulocyte recruitment. Because $\mathrm{PAR}_{2}$ is expressed both on endothelial cells and on CD45-positive cells, it is difficult to conclude on the cellular origin responsible for $\mathrm{PAR}_{2}$-associated leukocyte recruitment. Hyun et al ${ }^{59}$ have recently shown that $\mathrm{PAR}_{2}$ plays an important role in up-regulating the expression of adhesion molecules ICAM- 1 and V-CAM- 1 in three different models of colitis, and further demonstrated that $\mathrm{PAR}_{2}$ expression both on bone marrow-derived cells and in host-derived tissues was important for regulating granulocyte recruitment. ${ }^{58} \mathrm{~A}$ similar role for $\mathrm{PAR}_{2}$ could be hypothesized in our model of ischemia-reperfusion. In contrast, $\mathrm{PAR}_{1}$ activation could be restricted to endothelial cells as no colocalization was observed for $\mathrm{PAR}_{1}$ with the CD45 marker.

Taken together, these findings suggest that the serine protease release induced by I-R occurs independently of $\mathrm{PAR}_{1}$ or $\mathrm{PAR}_{2}$ activation, but that $\mathrm{PAR}_{1}$ and $\mathrm{PAR}_{2}$ activation represents a most important step upstream from protease-dependent post-ischemic granulocyte recruitment. Those different subtypes of receptors seem to have distinct but complementary roles in granulocyte recruitment, having distinct mechanisms of action and distinct patterns of expression in the small intestine. Finally, it is important to consider that $\mathrm{PAR}_{1}$ and $\mathrm{PAR}_{2}$ are not necessarily activated by the same serine proteases. For instance, $P A R_{1}$, but not $P A R_{2}$, is activated by thrombin whereas $P A R_{2}$, but not $P A R_{1}$, is activated by tryptase. In contrast, trypsin, which we have shown to be significantly present in I-R tissues, can activate both receptors.

In conclusion, the present study suggests that serine proteases and PAR activation are involved in the pathogenesis of intestinal IRI. These findings feed our understanding of the IRI pathogenesis, pointing to a role for arginine-specific cleavage proteases, and $\mathrm{PAR}_{1} / \mathrm{PAR}_{2}$ activation. Re-equilibrating the tissue protease/antiprotease balance in ischemia-reperfusion processes actively protects from injury and death, and the use of a broad, large-spectrum protease inhibitor such as FUT-175, also available commercially as Nafamostat, could represent an interesting therapeutic option to prevent local and systemic consequences of intestinal IRI.

\section{References}

1. Collard CD, Gelman S: Pathophysiology, clinical manifestations, and prevention of ischemia-reperfusion injury. Anesthesiology 2001, 94: 1133-1138

2. Mallick IH, Yang W, Winslet MC, Seifalian AM: Ischemia-reperfusion injury of the intestine and protective strategies against injury. Dig Dis Sci 2004, 49:1359-1377

3. Oldenburg WA, Lau LL, Rodenberg TJ, Edmonds HJ, Burger CD Acute mesenteric ischemia: a clinical review. Arch Intern Med 2004 164:1054-1062

4. Van Leeuwen PA, Boermeester MA, Houdijk AP, Ferwerda CC Cuesta MA, Meyer S, Wesdorp RI: Clinical significance of translocation. Gut 1994, 35:S28-S34

5. Cerqueira NF, Hussni CA, Yoshida WB: Pathophysiology of mesenteric ischemia/reperfusion: a review. Acta Cir Bras 2005, 20:336-343

6. Gatt M, Reddy BS, MacFie J: Review article: bacterial translocation in the critically ill: evidence and methods of prevention. Aliment Pharmacol Ther 2007, 25:741-757

7. Vergnolle N: Proteinase-activated receptors (PARs) in infection and inflammation in the gut. Int J Biochem Cell Biol 2008, 40:1219-1227

8. Vergnolle N: Protease-activated receptors as drug targets in inflammation and pain. Pharmacol Ther 2009, 123:292-309

9. Vergnolle $\mathrm{N}$ : Clinical relevance of proteinase activated receptors (PARs) in the gut. Gut 2005, 54:867-874

10. Vergnolle N, Ferazzini M, D'Andrea MR, Buddenkotte J, Steinhoff M: Proteinase-activated receptors: novel signals for peripheral nerves. Trends Neurosci 2003, 26:496-500

11. Vergnolle N: Review article: proteinase-activated receptors-novel signals for gastrointestinal pathophysiology. Aliment Pharmacol Ther 2000, 14:257-266 
12. Vergnolle N, Wallace JL, Bunnett NW, Hollenberg MD: Proteaseactivated receptors in inflammation, neuronal signaling and pain. Trends Pharmacol Sci 2001, 22:146-152

13. Houle S, Papez MD, Ferazzini M, Hollenberg MD, Vergnolle N: Neutrophils and the kallikrein-kinin system in proteinase-activated receptor 4-mediated inflammation in rodents. Br J Pharmacol 2005, 146 : $670-678$

14. Vergnolle N, Hollenberg MD, Sharkey KA, Wallace JL: Characterization of the inflammatory response to proteinase-activated receptor-2 (PAR-2)-activating peptides in the rat paw. Br J Pharmacol 1999 127:1083-1090

15. Vergnolle N, Hollenberg MD, Wallace JL: Pro- and anti-inflammatory actions of thrombin: a distinct role for proteinase-activated receptor-1 (PAR1). Br J Pharmacol 1999, 126:1262-1268

16. Cenac N, Cellars L, Steinhoff M, Andrade-Gordon P, Hollenberg MD, Wallace JL, Fiorucci S, Vergnolle N: Proteinase-activated receptor-1 is an anti-inflammatory signal for colitis mediated by a tpe 2 immune response. Inflamm Bowel Dis 2005, 11:792-798

17. Cenac N, Coelho AM, Nguyen C, Compton S, Andrade-Gordon P, MacNaughton WK, Wallace JL, Hollenberg MD, Bunnett NW, GarciaVillar R, Bueno L, Vergnolle N: Induction of intestinal inflammation in mouse by activation of proteinase-activated receptor-2. Am J Pathol 2002, 161:1903-1915

18. Ferazzini M, Santi S, Macnaughton WK, Hollenberg MD, Wallace JL, Vergnolle N: Proteinase-activated receptor-4 (PAR4) is implicated in the pathogenesis of dextran sodium sulfate colitis (abstract). Gastroenterology 2003, A-487124

19. Nguyen C, Coelho AM, Grady E, Compton SJ, Wallace JL, Hollenberg MD, Cenac N, Garcia-Villar R, Bueno L, Steinhoff M, Bunnett NW Vergnolle N: Colitis induced by proteinase-activated receptor-2 agonists is mediated by a neurogenic mechanism. Can J Physiol Pharmacol 2003, 81:920-927

20. Vergnolle N, Cellars L, Mencarelli A, Rizzo G, Swaminathan S, Beck P, Steinhoff M, Andrade-Gordon P, Bunnett NW, Hollenberg MD, Wallace JL, Cirino G, Fiorucci S: A role for proteinase-activated receptor-1 in inflammatory bowel diseases. J Clin Invest 2004, 114: 1444-1456

21. Chin AC, Lee WY, Nusrat A, Vergnolle N, Parkos CA: Neutrophilmediated activation of epithelial protease-activated receptors-1 and -2 regulates barrier function and transepithelial migration. J Immunol 2008, 181:5702-5710

22. Shimoda N, Fukazawa N, Nonomura K, Fairchild RL: Cathepsin G is required for sustained inflammation and tissue injury after reperfusion of ischemic kidneys. Am J Pathol 2007, 170:930-940

23. Fowell AJ, Benyon RC: Can matrix metalloproteinases be targeted in hepatic ischemia/reperfusion injury?. Hepatology 2008, 47:14-16

24. Uchida Y, Freitas MC, Zhao D, Busuttil RW, Kupiec-Weglinski JW: The inhibition of neutrophil elastase ameliorates mouse liver damage due to ischemia and reperfusion. Liver Transpl 2009, 15:939-947

25. Donato M, D'Annunzio V, Buchholz B, Miksztowicz V, Carrion CL, Valdez LB, Zaobornyj T, Schreier L, Wikinski R, Boveris A, Berg G, Gelpi RJ: Role of matrix metalloproteinase-2 in the cardioprotective effect of ischaemic postconditioning. Exp Physiol 2010, 95:274-281

26. Schwertz H, Carter JM, Russ M, Schubert S, Schlitt A, Buerke U, Schmidt M, Hillen H, Werdan K, Buerke M: Serine protease inhibitor nafamostat given before reperfusion reduces inflammatory myocardial injury by complement and neutrophil inhibition. J Cardiovasc Pharmacol 2008, 52:151-160

27. Calcina F, Sternini C, Ghizzardi P, Cattaruzza F, Bertoni S, Ballaben V, Impicciatore M, Barocelli E: Protective effects of a protease inhibitor (gabexate mesilate) on intestinal ischemia/reperfusion injury in rats (abstract). Gastroenterology 2004, 126:A256

28. Ishimaru K, Mitsuoka H, Unno N, Inuzuka K, Nakamura S, SchmidSchonbein GW: Pancreatic proteases and inflammatory mediators in peritoneal fluid during splanchnic arterial occlusion and reperfusion. Shock 2004, 22:467-471

29. Steinhoff M, Vergnolle N, Young SH, Tognetto M, Amadesi S, Ennes HS, Trevisani M, Hollenberg MD, Wallace JL, Caughey GH, Mitchell SE, Williams LM, Geppetti P, Mayer EA, Bunnett NW: Agonists of proteinase-activated receptor 2 induce inflammation by a neurogenic mechanism. Nat Med 2000, 6:151-158

30. Vergnolle N, Bunnett NW, Sharkey KA, Brussee V, Compton SJ, Grady EF, Cirino G, Gerard N, Basbaum Al, Andrade-Gordon P,
Hollenberg MD, Wallace JL: Proteinase-activated receptor-2 and hyperalgesia: a novel pain pathway. Nat Med 2001, 7:821-826

31. Motta JP, Magne L, Descamps D, Rolland C, Squarzoni-Dale C, Rousset P, Martin L, Cenac N, Balloy V, Huerre M, Jenne D, Wartelle J, Belaaouaj A, Mas E, Vinel JP, Alric L, Chignard M, Vergnolle N, Sallenave JM: Modifying the protease, antiprotease pattern by elafin overexpression protects mice from colitis. Gastroenterology 2011 , 140:1272-1282

32. Cenac N, Andrews CN, Holzhausen M, Chapman K, Cottrell G, Andrade-Gordon P, Steinhoff M, Barbara G, Beck P, Bunnett NW, Sharkey KA, Ferraz JG, Shaffer E, Vergnolle N: Role for protease activity in visceral pain in irritable bowel syndrome. J Clin Invest 2007, 117:636-647

33. Sarin A, Adams DH, Henkart PA: Protease inhibitors selectively block $T$ cell receptor-triggered programmed cell death in a murine $T$ cell hybridoma and activated peripheral T cells. J Exp Med 1993, 178 : 1693-1700

34. Barrett AJ, Kembhavi AA, Brown MA, Kirschke H, Knight CG, Tamai M, Hanada K: L-trans-Epoxysuccinyl-leucylamido(4-guanidino)butane (E-64) and its analogues as inhibitors of cysteine proteinases including cathepsins B, H and L. Biochem J 1982, 201:189-198

35. Murao S, Ohkuni K, Nagao M, Hirayama K, Fukuhara K, Oda K, Oyama $\mathrm{H}$, Shin T: Purification and characterization of kumamolysin, a novel thermostable pepstatin-insensitive carboxyl proteinase from Bacillus novosp. MN-32. J Biol Chem 1993, 268:349-355

36. Lawson WB, Valenty VB, Wos JD, Lobo AP: Studies on the inhibition of human thrombin: effects of plasma and plasma constituents. Folia Haematol Int Mag Klin Morphol Blutforsch 1982, 109:52-60

37. Markwardt F, Drawert J, Walsmann P: Synthetic low molecular weight inhibitors of serum kallikrein. Biochem Pharmacol 1974, 23:22472256

38. Cattaruzza F, Cenac N, Barocelli E, Impicciatore M, Hyun E, Vergnolle N, Sternini C: Protective effect of proteinase-activated receptor 2 activation on motility impairment and tissue damage induced by intestinal ischemia/reperfusion in rodents. Am J Pathol 2006, 169: $177-188$

39. D'Aldebert E, Cenac N, Rousset P, Martin L, Rolland C, Chapman K, Selves J, Alric L, Vinel JP, Vergnolle N: Transient receptor potential vanilloid 4 activated inflammatory signals by intestinal epithelial cells and colitis in mice. Gastroenterology 2011, 140:275-285

40. Cenac N, Altier C, Motta JP, d'Aldebert E, Galeano S, Zamponi GW, Vergnolle N: Potentiation of TRPV4 signalling by histamine and serotonin: an important mechanism for visceral hypersensitivity. Gut 2010, 59:481-488

41. Cenac N, Altier C, Chapman K, Liedtke W, Zamponi G, Vergnolle N: Transient receptor potential vanilloid-4 has a major role in visceral hypersensitivity symptoms. Gastroenterology 2008, 135:937-946

42. Aoyama T, Ino Y, Ozeki M, Oda M, Sato T, Koshiyama Y, Suzuki S, Fujita M: Pharmacological studies of FUT-175, nafamstat mesilate. I Inhibition of protease activity in in vitro and in vivo experiments. Jpn J Pharmacol 1984, 35:203-227

43. Perretti M, Getting SJ: Migration of specific leukocyte subsets in response to cytokine or chemokine application in vivo. Methods Mol Biol 2003, 225:139-146

44. Cottrell GS, Amadesi S, Grady EF, Bunnett NW: Trypsin IV, a novel agonist of protease-activated receptors 2 and 4. J Biol Chem 2004, 279:13532-13539

45. Koshikawa N, Hasegawa S, Nagashima Y, Mitsuhashi K, Tsubota Y, Miyata S, Miyagi Y, Yasumitsu H, Miyazaki K: Expression of trypsin by epithelial cells of various tissues, leukocytes, and neurons in human and mouse. Am J Pathol 1998, 153:937-944

46. Koshikawa N, Nagashima Y, Miyagi Y, Mizushima H, Yanoma S, Yasumitsu $\mathrm{H}$, Miyazaki K: Expression of trypsin in vascular endothelial cells. FEBS Lett 1997, 409:442-448

47. Lawrence DA, Loskutoff DJ: Inactivation of plasminogen activator inhibitor by oxidants. Biochemistry 1986, 25:6351-6355

48. Stief TW, Lenz P, Becker U, Heimburger N: Determination of plasminogen activator inhibitor (PAI) capacity of human plasma in presence of oxidants: a novel principle. Thromb Res 1988, 50:559-573

49. Stief TW, Aab A, Heimburger N: Oxidative inactivation of purified human alpha-2-antiplasmin, antithrombin III, and C1-inhibitor. Thromb Res 1988, 49:581-589 
50. Stief TW, Heimburger N: Inactivation of serine proteinase inhibitors (serpins) in human plasma by reactive oxidants. Biol Chem Hoppe Seyler 1988, 369:1337-1342

51. Stief TW, Kropf J, Kretschmer V, Doss MO, Fareed J: Singlet oxygen ((1)O2) inactivates plasmatic free and complexed alpha2-macroglobulin. Thromb Res 2000, 98:541-547

52. Sun Z, Wang X, Deng X, Lasson A, Wallen R, Hallberg E, Andersson $\mathrm{R}$ : The influence of intestinal ischemia and reperfusion on bidirectional intestinal barrier permeability, cellular membrane integrity, proteinase inhibitors, and cell death in rats. Shock 1998, 10:203-212

53. Olanders K, Sun Z, Borjesson A, Dib M, Andersson E, Lasson A, Ohlsson T, Andersson R: The effect of intestinal ischemia and reperfusion injury on ICAM-1 expression, endothelial barrier function, neutrophil tissue influx, and protease inhibitor levels in rats. Shock 2002, 18:86-92

54. Pierro A, Eaton S: Intestinal ischemia reperfusion injury and multisystem organ failure. Semin Pediatr Surg 2004, 13:11-17

55. Lefer AM: The pathophysiologic role of myocardial depressant factor as a mediator of circulatory shock. Klin Wochenschr 1982, 60:713-716

56. Wang H, Moreau F, Hirota CL, MacNaughton WK: Proteinase-activated receptors induce interleukin-8 expression by intestinal epithe- lial cells through ERK/RSK90 activation and histone acetylation. FASEB J 2010, 24:1971-1980

57. Tanaka $Y$, Sekiguchi F, Hong H, Kawabata A: PAR2 triggers IL-8 release via MEK/ERK and PI3-kinase/Akt pathways in Gl epithelial cells. Biochem Biophys Res Commun 2008, 377:622-626

58. Hyun E, Andrade-Gordon P, Steinhoff M, Beck PL, Vergnolle N: Contribution of bone marrow-derived cells to the pro-inflammatory effects of protease-activated receptor-2 in colitis. Inflamm Res 2010, 59:699-709

59. Hyun E, Andrade-Gordon P, Steinhoff M, Vergnolle N: Proteaseactivated receptor-2 activation: a major actor in intestinal inflammation. Gut 2008, 57:1222-1229

60. Hyun E, Ramachandran R, Cenac N, Houle S, Rousset P, Saxena A Liblau RS, Hollenberg MD, Vergnolle N: Insulin modulates proteaseactivated receptor 2 signaling: implications for the innate immune response. J Immunol 2010, 184:2702-2709

61. Rahman A, True AL, Anwar KN, Ye RD, Voyno-Yasenetskaya TA, Malik AB: Galpha and Gbetagamma regulate PAR-1 signaling of thrombin-induced NF-kappaB activation and ICAM-1 transcription in endothelial cells. Circ Res 2002, 91:398-405 